\title{
Etiological and Demographic Characteristics of Patients with Vestibular Symptoms, Retrospective Analysis
}

\author{
Baş Dönmesi Şikayeti Olan Hastaların Etiyolojik ve Demografik Özellikleri, Retrospektif \\ Incelemesi
}

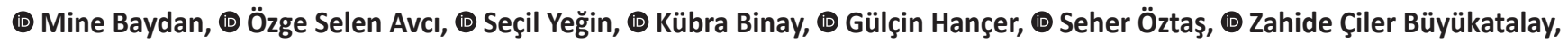 \\ (1) Suna Yılmaz
}

Ankara University Faculty of Medicine, Department of Audiology, Ankara, Turkey

\section{Abstract}

Objectives: Vertigo and dizziness are among the most common causes of medical consultation, with an estimated prevalence of $20 \%$ and $30 \%$. Vertigo and/or dizziness are non-specific symptoms that can be caused by various disorders including central and peripheral disorders. The present study aimed to understand etiological and demographic characteristics of patients with vestibular symptoms.

Materials and Methods: Retrospective analysis of medical profiles of patients who suffered from vertigo and/or dizziness and sought medical advice from Ankara University İbn-i Sina Hospital otorhinolaryngology Department, Hearing, Speaking and Balance Disorders Center between September 2018 and September 2019 was performed.

Results: A total of 444 patients between the age of 6 and 89 years were included in the study. Disregarding age groups and underlying cause, it was observed that women were more frequently affected by vertigo/dizziness. The most frequent cause of vertigo/dizziness was benign paroxysmal positional vertigo (59.23\%) followed by unilateral/bilateral vestibular hypofunction (20.72\%), central pathologies (14.63\%). Meniere's disease (3.60\%) and vestibular neuritis (1.80\%). Central vestibular disorders were found to be the most common pathology in children (53.84\%).

Conclusion: The most common disorder was the peripheral vestibular disorder and the most common diagnosis was benign paroxysmal positional vertigo in adults. Central vestibular disorders were recorded as the most common pathology in children. Optimal diagnosis of vertigo/dizziness related disorders requires a multidisciplinary approach.

Key Words: Vertigo, Dizziness, Retrospective Analysis

\section{Özet}

Amaç: Baş dönmesi ve dengesizlik \%20-30'luk yaygınlık oranı ile tıbbi konsültasyonun en yaygın nedenleri arasındadır. Baş dönmesi ve/veya dengesizlik spesifik olmayan semptomlardır, santral ve periferik bozukluklar da dahil olmak üzere çeşitli bozukluklardan kaynaklanabilir. Bu çalışmada vestibüler semptomları olan hastaların etiyolojik ve demografik özelliklerinin anlaşılması amaçlanmıştır.

Gereç ve Yöntem: Eylül 2018-Eylül 2019 tarihleri arasında Ankara Üniversitesi İbn-i Sina Hastanesi Kulak Burun Boğaz Anabilim Dalı Işitme, Konuşma ve Denge Bozuklukları Merkezi'ne baş dönmesi ve/veya dengesizlik şikayeti ile başvuran hastaların tıbbi profilleri retrospektif olarak incelenmiştir.

Bulgular: Çalışmaya 6 ila 89 yaş arası toplam 444 hasta dahil edilmiştir. Yaş grupları ve altta yatan neden göz ardı edildiğinde, kadınların baş dönmesi/dengesizlikten daha sık etkilendiği gözlenmiştir. Baş dönmesi/dengesizliğin en sık nedeni benign paroksismal pozisyonel vertigo (\%59,23) ve ardından unilateral/bilateral vestibüler hipofonksiyon $(\% 20,72)$, santral patolojiler $(\% 14,63)$, Meniere hastalığı $(\% 3,60)$ ve vestibüler nörinit $(\% 1,80)$ olarak gözlenmiştir. Santral vestibüler bozukluklar çocuklarda en sık görülen patolojidir $(\% 53,84)$.

Sonuç: Yetişkinlerde en sık görülen rahatsızlık periferik vestibüler bozukluk ve en sık rastlanan tanı benign paroksismal pozisyonel vertigo idi. Santral vestibüler bozukluklar çocuklarda en sık görülen patoloji olarak kaydedildi. Baş dönmesi/dengesizlik ile ilişkili bozuklukların optimal tanısı için multidisipliner bir yaklaşım gerekmektedir.

Anahtar Kelimeler: Baş Dönmesi, Dengesizlik, Retrospektif Analiz

Address for Correspondence/Yazışma Adresi: Dr. Mine Baydan, MD,

Ankara University Faculty of Medicine, Department of Audiology, Ankara, Turkey

Phone: +90 3123195018 E-mail: mine.baydan@gmail.com ORCID: orcid.org/0000-0003-2836-0799

Received/Geliş Tarihi: 09.06.2020 Accepted/Kabul Tarihi: 17.08.2020

๑Copyright 2020 Ankara University Faculty of Medicine

Journal of Ankara University Faculty of Medicine is published by Galenos Publishing House.

All content are under CC BY-NC-ND license. 


\section{Introduction}

Vertigo and/or dizziness is the most common cause of emergency department, neurology, otorhinolaryngology and audiology clinics visits, affecting 20-30\% of the general population $(1,2)$. The underlying causes of vertigo and/or dizziness can be by a bundle of etiologies, including central or peripheral disorders, central nervous system disease, psychiatric disease and cardiovascular processes (3).

The medical history is an important part of diagnostic assessment and a structured medical history including questions about the severity and frequency of complaints, characteristics of vertigo, provokers of symptoms, drug use, hearing loss, additional systemic diseases may be useful for differential diagnosis (4). Bedside testing is also the principal diagnostic procedure for evaluating patients suffering from vertigo (5). Beside these, a series of laboratory tests are used for the differential diagnosis. These tests are used to differentiate central/peripheral pathology and to locate the peripheral lesion (6). In some cases, because of the complex etiology of vertigo, diagnosis requires multidisciplinary approaches including neurology, otorhinolaryngology, ophthalmology, and physiotherapy (7).

Knowing the etiological and demographic characteristics of dizziness and balance disorders, which involve various systems and concern many disciplines, affecting the quality of life of patients, facilitates the diagnosis and treatment. At the same time, such information prevents loss of time in deciding which diagnostic approach to apply on which patient.

This study includes a retrospective review of the etiologic and demographic characteristics of dizziness patients admitted to our clinic in order to understand the incidence and characteristics of dizziness. The main purpose of the study is to define the incidence and characteristics of the patients who suffered from vertigo and/or dizziness. The second aim is to examine the differences between the groups by examining the patients according to their age, gender, symptoms and findings.

\section{Materials and Methods}

The study was approved by Ankara University Faculty of Medicine Human Research Ethics Committee (no: I6-27019). This study is restricted to the data of patients admitted at Ankara University School of Medicine İbn-i Sina Hospital, Otorhinolaryngology Department, Hearing, Speaking and Balance Disorders Center between September 2018 and September 2019 with dizziness/balance disorder. The patients were referred from otorhinolaryngologists and neurologists, and information related to the age, gender, medical history and laboratory tests for diagnosis and diagnostic information were collected from medical records. Bedside examinations including head impulse, skew deviation and spontaneous nystagmus, were performed. All patients were examined by otoscopy, tympanometry, stapedial reflex examination, pure tone audiometry and videonystagmography as standard test battery. In the diagnostic process, vestibular evoked myogenic potentials, video head impulse test, caloric test, functional head impulse test and computerized dynamic posturography tests were carried out in addition to the standard test battery when necessary. Diagnosing criteria used in peripheral and central pathologies are listed in Table 1.

The patients were referred to related medical departments according to diagnoses (otorhinolaryngology, neurology, cardiology, etc.) for medical treatment or radiological evaluation. Patients without central or peripheral vestibular pathology, and

\footnotetext{
Table 1: Diagnostic criteria used for peripheral and central pathologies

Diagnoses

Criteria

Peripheral pathologies

Benign paroxysmal positional vertigo

Unilateral/bilateral hypofunction

Meniere's disease

Vestibular neuritis

Central pathologies

Vestibular migraine

Vertebrobasilar insufficiency

Other central pathologies

CDP: Computerized dynamic posturography, FHIT: Functional head impulse test, VEMP: Vestibular evoked myogenic potentials, HNS: Head and neck surgery

*VHIT: Video-head impulse test

Positive provocation maneuvers and canal specific nystagmus

Caloric weakness in one or both ears, low VHIT* gain in one or both ear, pathologic CDP *results

Consensus Document of the Barany Society, the Japan Society for Equilibrium Research, the European Academy of Otology and Neurotology, the American Academy of Otolaryngology-Head and Neck Surgery (AA0-HNS) and the Korean Balance Society (31), pathologic VEMP results

Sudden onset vertigo, spontaneous nystagmus, absence of hearing loss, tinnitus and neurological symptoms

Consensus Document of Barany Society and the International Headache Society (32), pathological FHIT* results

Doppler ultrasonography

$\left(\frac{100}{20}\right.$


patients with cardiac, hematological and orthopedic balance disorders were excluded from this study.

\section{Statistical Analysis}

Statistical analyses were performed using IBM SPSS 23.0 package program. Numerical variables were expressed as mean and standard deviation, and number and percentage indicated categorical variables.

\section{Results}

In total 557 patient records were examined, and 113 subjects were excluded from the study because the etiology of the vestibular disorder was cardiac, hematological and orthopedic balance disorders. Of these 444 patients, 315 were women and 129 were men, corresponding to the gender distribution of $70.94 \%$ women to $29.05 \%$ men. The patients were divided into three groups. "Group 1" consisted of the patients under 18, "group 2" consisted of the patients between 18-64 years of age and "group 3" consisted of the patients age over 65 . Patients between $18-64$ years of age consisted $70.27 \%$ of the study group. The age and gender distribution of the patients by groups are shown in Table 2.

It was found that $68.04 \%$ of the patients suffered from peripheral vertigo, which mainly includes benign paroxismal positional vertigo (BPPV), unilateral or bilateral vestibular hypofunction, Meniere's disease and vestibular neuritis; whereas, $11.66 \%$ of the patients suffered from central vertigo, which includes vestibular migraine, vertebrobasilar insufficiency and rarer disorders such as multiple sclerosis, vascular loop, intracranial mass (medullablastoma), ischemia, polyneuropathy, myasthenia gravis. BPPV was the most common cause of vertigo, with a prevalence of $59.23 \%$, followed by unilateral/ bilateral vestibular hypofunction with a prevalence of $20.72 \%$ and central pathologies with a prevalence of $14.63 \%$. In the present study, the least common causes of vertigo were Meniere's disease $(3.60 \%)$ and vestibular neuritis (1.80\%). The overall distribution of the diagnoses is shown in Figure 1, while and the distribution of diagnoses by groups is given in Table 3 .

One hundred and ninety-two of the patients diagnosed with BPPV were female (73\%), whereas and 71 were male $(23 \%)$. BPPV was most frequently seen in women aged between 18 and 64. In group 2, 185 patients were diagnosed with BPPV, 139 of whom were female $(75.13 \%)$. In group 3, 77 subjects were diagnosed with BPPV and 52 of them were female $(67,53 \%)$.

The most common involved canal in BPPV was posterior semicircular canal (62.73\% of all BPPV cases) followed by lateral semicircular canal (15.58\% of all BPPV cases) and multiple canals (10.64\% of all BPPV cases). Anterior canal BPPV was found only in $7.22 \%$ of all BPPV cases. Except for the multicanal BPPVs, the right ear (60.85\%) was the most commonly affected ear; $42.97 \%$ of patients had right posterior canal BPPV, $12.34 \%$ of patients had right lateral canal BPPV and 5.53\% of patients had right anterior canal BPPV. It was observed that $39.15 \%$ of BPPV patients suffered from left ear BBPV, of which 27.23\% were left posterior canal, 9.36\% were left lateral and 2.55\% were left anterior.

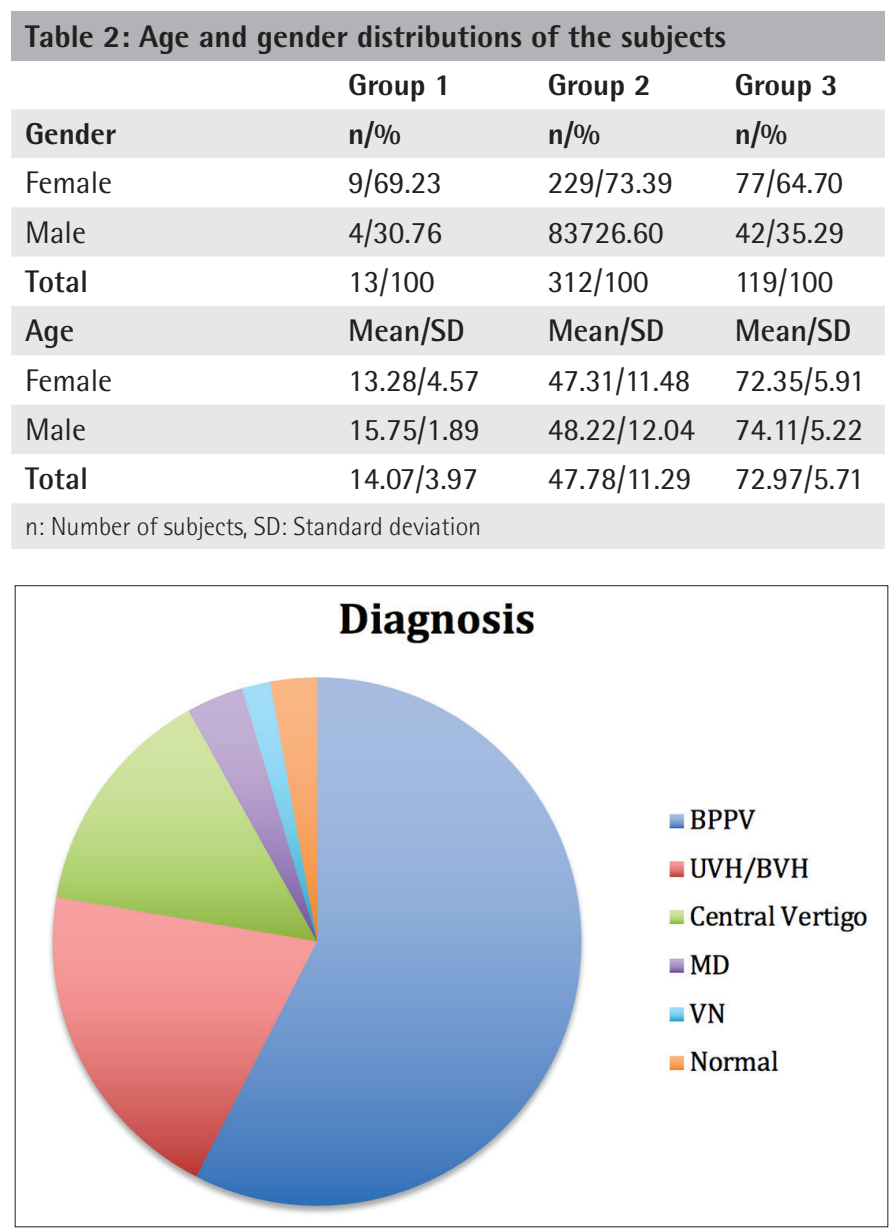

Figure 1: The distribution of diagnosis

BPPV: Benign paroxysmal positional vertigo, UVH/BVH: Unilateral vestibular dysfunction/bilateral vestibular dysfunction, MD: Meniere's disease, VN: Vestibular neuritis

\begin{tabular}{lllll}
\multicolumn{5}{l}{ Table 3: The Distribution of Diagnosis by Groups } \\
Diagnosis & Group 1 & Group 2 & Group 3 & Total/\% \\
\hline BPPV & 1 & 185 & 77 & $263 / 59.23$ \\
UVH/BVH & 5 & 71 & 16 & $92 / 20.72$ \\
\hline Central Vertigo & 7 & 34 & 24 & $65 / 14.63$ \\
MD & - & 16 & - & $16 / 3.60$ \\
VN & - & 6 & 2 & $8 / 1.80$ \\
Total & 13 & 312 & 119 & $444 / 100$ \\
& $(2.92 \%)$ & $(70.27 \%)$ & $(26.80 \%)$ &
\end{tabular}

BPPV: Benign paroxysmal positional vertigo, UVH/BVH: Unilateral vestibular dysfunction/bilateral vestibular dysfunction, MD: Meniere's disease, VN: Vestibular neuritis 
The total number of patients diagnosed with unilateral/ bilateral vestibular hypofunction was 92 (16.51\%); 63 (68.47\%) were female, 29 (31.52\%) were male. Meniere's disease was diagnosed in $16(2.87 \%)$ patients; 13 (81.25\%) female and three $(18.75 \%)$ male; whereas vestibular neuritis was diagnosed in eight (1.43\%) patients; four (50\%) female and four (50\%) male.

Central vertigo was diagnosed in $11.66 \%$ of the patients. The most common cause of central vertigo was vestibular migraine (15.38\%) followed by vertebrobasilar insufficiency (13.84\%).

\section{Discussion}

Detailed medical history, bedside tests, laboratory tests and multidisciplinary approach are crucial for diagnosis as well as for differentiating peripheral and central vertigo and treatment. In the evaluation of patients with vestibular symptoms, the characteristics of vestibular symptoms, and gender, age and other accompanying symptoms and comorbidities play an important role as well. In fact, thanks to the diagnostic algorithms to be designed according to this information, the most appropriate diagnostic tests can be planned for the patient, preventing unnecessary vestibular tests that would cause loss of time and money.

Staibano et al. (3) described the clinical characteristics of patients presenting dizziness and found that $66.4 \%$ of 292 patients were female. Yin et al. (8), in their clinical epidemiologic study of vertigo found that $59.28 \%$ of 2,169 patients were female. Bittar et al. (9) analyzed the prevalence of dizziness in the city of Sao Paulo and revealed that the 53\% of 1,960 patients were women. Regardless of the age groups and underlying cause, it was observed that women were more frequently affected by vertigo/dizziness in this study, which is also in conformity with the literature.

As we investigate the distribution of age groups, it is observed that the group between 18-64 years of age has the highest number of patients. More frequent vestibular symptoms in this age group, which is active in business and social life, is associated with an important health burden, underlying the importance of diagnosis in primary care.

In the present study, it was analyzed that $68.04 \%$ of 444 patients suffered from peripheral vestibular disorders including BPPV, Meniere's disease, vestibular neuritis and vestibular hypofunction. In accordance with the literature $(10,11)$ the most common peripheral disorder was BPPV and an increase is recorded in both younger (18-64 years) and older (64+) age groups. The most involved canal was the posterior canal followed by lateral and anterior canals. The right ear was more commonly affected than the left ear, and these findings are consistent with the previously reported findings (10-16).
Unilateral/bilateral vestibular hypofunction was the second most common diagnosis of the patients visiting our clinic with vertigo/dizziness. In the present study, the third peripheral cause of vertigo was Meniere's disease with a rate of $3.60 \%$. In the literature, Meniere's disease is among the top four causes of vertigo $(5,17-19)$. Diagnosis and treatment of Meniere's disease is difficult and controversial (20). It makes the diagnosis more difficult for patients who are admitted at the emergency departments during the attack periods and at the otolaryngology clinics after the acute period. In our study, it is thought that this diagnostic difficulty is the reason for the low prevalence, despite being the third main cause. Previous studies have shown that there is a gender related difference in Meniere's disease, as more women than men are affected (19, 21-23). In this study as well, it was found that women (81.25\%) were slightly more affected than men.

It was recorded that, $1.43 \%$ of 444 patients were diagnosed with vestibular neuritis. Since vestibular neuritis is a very rare pathology that may cause diagnostic difficulties for physicians of different specialties, and because of the severity of acute symptoms, these patients may delay their admission to otorhinolaryngology clinics. This can cause diagnostic delay and affect the incidence rate.

The diagnosis of central vestibular pathology is challenging and sometimes symptoms and signs may overlap with peripheral vestibular pathology (24). Optimal diagnostic and therapeutic strategies should involve a multidisciplinary approach including the ear, nose, throat, neurology, ophthalmology and neurosurgery (7). Central vertigo was found in $11.65 \%$ of 557 patients, 15.38\% of whom were diagnosed with vestibular migraine and 13.84\% were diagnosed with vertebrobasilar insufficiency.

Vestibular migraine (VM) is common but underdiagnosed in the general population because of diagnostic difficulties and has a considerable healthcare burden (25). There are a couple of articles in the literature including findings that support female preponderance in VM (26-28). In accordance with the literature, of the patients who were diagnosed with $\mathrm{VM}, 66.6 \%$ were female and $33.3 \%$ were male in the present study.

When a child complains of dizziness, there is a tendency to underestimate this symptom. According to our experience, families often think that the child expresses himself incorrectly, is worrying about exams/stressed about school, or trying to attract attention. This underestimating can cause misdiagnosis or delay in diagnosis. Although, the sample size of group 1 is small, central vertigo was observed as the most common pathology in children. Li et al. (29), stated that dizziness and balance problems in childhood could be a symptom of neurologic abnormality and they should undergo a through neurological physical examination. O'Reilly et al. (30) aimed to determine the prevalence of vestibular and balance disorders in children, and 
found that $21 \%$ of children suffered from central disturbances (30). In view of the fact that high rates of central pathologies are seen in children and vertigo might present a considerable pathology, they should be referred to undergo additional tests or further evaluation performed by either an otolaryngologist or a neurologist (19).

\section{Study Limitations}

A limitation of the present study is that the patients seen at the vertigo and balance disorders clinics are by no means representative of the population of vertigo/dizziness in Turkey. However, to the best of our knowledge, this study is the first survey on dizziness from an audiology clinic in Turkey.

\section{Conclusion}

Peripheral vestibular disorders were found to be common across the age groups over 18. Each diagnosis was specifically distributed across all age groups and both genders. Overall, women are more frequently affected by vestibular disorders than men. Central vestibular disorders were recorded as the most common pathology in children. Optimal diagnosis of vertigo/ dizziness related disorders requires a multidisciplinary approach.

\section{Ethics}

Ethics Committee Approval: This study was approved by Ankara University Faculty of Medicine Human Research Ethics Committee (no: í6-270-19).

\section{Informed Consent: Retrospective study.}

Peer-review: Externally peer-reviewed.

\section{Authorship Contributions}

Surgical and Medical Practices: Z.Ç.B., Concept: M.B., Design: M.B., G.H., S.Y., K.B., Ö.S.A., S.Ö., Data Collection or Processing: M.B., G.H., S.Y., K.B., Ö.S.A., S.Ö., Z.Ç.B., S.Y., Literature Search: M.B., G.H., S.Y., K.B., Ö.S.A., S.Ö., Writing: M.B., G.H., S.Y., K.B., Ö.S.A., S.Ö., Z.Ç.B., S.Y.

Conflict of Interest: No conflict of interest was declared by the authors.

Financial Disclosure: The authors declared that this study received no financial support.

\section{References}

1. Numata K, Shiga T, Omura K, et al. Comparison of acute vertigo diagnosis and treatment practices between otolaryngologists and non-otolaryngologists: A multicenter scenario-based survey. PloS One. 2019;14:e0213196.

2. Barbosa F, Villa TR. Vestibular migraine: diagnosis challenges and need for targeted treatment. Arq neuropsiquiat. 2016;74:416-422.

3. Staibano $P$, Lelli $D$, Tse D. A retrospective analysis of two tertiary care dizziness clinics: a multidisciplinary chronic dizziness clinic and an acute dizziness clinic. J Otolaryngol-Head N. 2019;48:1.
4. Walther LE. Current diagnostic procedures for diagnosing vertigo and dizziness. GMS current topics in otorhinolaryngology, head and neck surgery. 2017. doi: 10.3205/cto000141. eCollection 2017.

5. Geser R, Straumann D. Referral and final diagnoses of patients assessed in an academic vertigo center. Front neurol. 2012. doi: 10.3389/fneur.2012.00169.

6. Aminoff M. Vestibular laboratory testing. Electrodiagnosis in clinical neurology. Furman J, Wuyts FL. eds, Churchill Livingstone, 2005.

7. Spiegel $R$, Rust $H$, Baumann $T$, et al. Treatment of dizziness: an interdisciplinary update. Swiss med wkly. 2017;147:51-52.

8. Yin M, Ishikawa $K$, Wong WH, et al. A clinical epidemiological study in 2169 patients with vertigo. Auris Nasus Larynx. 2009;36:30-35.

9. Bittar RSM, Oiticica J, Bottino MA, et al. Population epidemiological study on the prevalence of dizziness in the city of São Paulo. Braz J Otorhinolaryngol. 2013;79:688-698.

10. Hornibrook J. Benign paroxysmal positional vertigo (BPPV): history, pathophysiology, office treatment and future directions. Int J Otolaryngol. $2011 ; 2011: 1-13$

11. Plodpai $Y$, Atchariyasathian $V$, Khaimook $W$. The characteristic differences of benign paroxysmal positional vertigo among the elderly and the younger patients: A 10-year retrospective review. J Med Assoc Thai. 2014;97:850855.

12. Kim HJ, Kim JS. The Patterns of recurrences in idiopathic Benign Paroxysmal Positional Vertigo and self-treatment evaluation. Front Neurol. 2017;8:690.

13. Yazıcı $A$, İnanç $Y$. evaluation of BPPV with vertebral artery values. Neuropsychiatr Dis Treat. 2018;14:1975-1979.

14. Parham K. Benign paroxysmal positional vertigo: an integrated perspective. Advances in Otolaryngology. 2014;2014:1-17.

15. Califano L, Salafia F, Mazzone S, et al. Anterior canal BPPV and apogeotropic posterior canal BPPV: two rare forms of vertical canalolithiasis. ACTA otorhinolaryngolo. 2014;34:189-197.

16. Vaduva C, Estéban-Sánchez J, Sanz-Fernández R, et al. Prevalence and management of post-BPPV residual symptoms. Eur Arch Oto-Rhino-L. 2018;275:1429-1437.

17. Hanley $\mathrm{K}, \mathrm{O}$ 'Dowd $\mathrm{T}$, Considine N. A systematic review of vertigo in primary care. Br J Gen Pract. 2001;51:666-671.

18. Grill $E$, Strupp $M$, Müller $M$, et al. Health services utilization of patients with vertigo in primary care: a retrospective cohort study. J Neurol. 2014;261:1492-1498.

19. Holgers KM, Finizia $C$. Health profiles for patients with Ménière's disease. Noise Health. 2001;4:71-80.

20. Hendrickson $M$, Honaker JA. Vestibular Dysfunction, Meniere's Disease. In: Kountakis S.E. (eds) Encyclopedia of Otolaryngology, Head and Neck Surgery. Springer, Berlin, Heidelberg, 2013.

21. Hülse $R$, Biesdorf $A$, Hörmann $K$, et al. Peripheral Vestibular Disorders: An Epidemiologic Survey in 70 Million Individuals. Otol Neurotol. 2019;40:8895.

22. Sürmeli M, Deveci I. Clinicopathologic Results in Meniere Disease: Evaluation of 80 patients. The Medical Journal Of Haydarpaşa Numune Training and Research Hospital. 2018;58:152-157.

23. Pyykkö I, Nakashima T, Yoshida T, et al. Meniere's disease: a reappraisal supported by a variable latency of symptoms and the MRI visualisation of endolymphatic hydrops. BMJ Open. 2013;3:e001555.

24. Mohamed ES. Predictors of central vestibular disorders from videonystagmography tests. Egyp J Otolaryngol. 2016;32:202.

25. Neuhaser HK, Radtke A, von Brevern M, et al. Migranious vertigo. Prevalence and impact on quality of life. 2006;67:1028-1033.

26. Vuković V, Plavec D, Galinović I, et al. Prevalence of vertigo, dizziness, and migrainous vertigo in patients with migraine. Headea. 2007;47:1427-1435.

27. Maslarova SBSS, Soldo SB, Pajić-Penavić I, et al. Vestibular migraine considering new diagnostic criteria. Neurol Croat. 2014;63:1-2.

28. Hsu LC, Wang SJ, Fuh JL. Prevalence and impact of migranious vertigo in mid-life women: a community-based study. Cephalalgia. 2010;31:77-83. 
29. Li CM, Hoffman HJ, Ward BK, et al. Epidemiology of dizziness and balance problems in children in the United States: a population-based study. Pediatrics. 2016;171:240-247.e3.

30. O'Reilly RC, Morlet $T$, Nicholas BD, et al. Prevalence of vestibular and balance disorders in children. Otol Neurotol. 2010;31:1441-1444.

31. Escamez JA, Carey J, Chung WH, et al. Diagnostic criteria for Menière's disease. Consensus document of the Bárány Society, The Japan Society for
Equilibrium Research, the European Academy of Otology and Neurotology (EAONO), the American Academy of Otolaryngology-Head and Neck Surgery (AAO-HNS) and the Korean Balance Society. Acta Otorrinolaringol Esp. 2016;67:1-7.

32. Lempert $\mathrm{T}$, Olesen J, Furman J, et al. Vestibular migraine: diagnostic criteria. Consensus document of the Barany Society and the International headache society. Revue Neurologique. 2014;170:401-406. 